\title{
TEACHING GRAMMAR THROUGH LITERATURE IN FOREIGN LANGUAGE LEARNING WITH GERMAN AS AN EXAMPLE ${ }^{1}$
}

\author{
Angelika Weber \\ University of Pretoria
}

Learning a language's grammar is frequently experienced as a complicated, abstract and often boring process. To alleviate this situation, scholars like Harald Weinrich advocate the use of literature in grammar teaching and learning. Literature has a very special potential of emotionally touching its readers, causing them to reflect on what they have read. In turn, readers can easily be animated to respond. This article attempts to demonstrate how the potential of literature can be used even in grammar teaching and learning to stimulate the learners emotionally and lead them towards writing their own personal response to the text. In this way, they have the opportunity to express themselves in the foreign language while at the same time applying the grammar they have learned. Although the example is based on teaching German as a foreign language, the principle underlying the proposed pedagogical sequences can be applied to the teaching and learning of other foreign languages as well.

KEYWORDS: creative writing; foreign language teaching and learning; literariness; literary texts; originality; textual grammar.

\section{INTRODUCTION}

Knowing foreign languages in this globalised world is a desirable and helpful skill, in spite of English being the lingua franca in large parts of the world. Because the ultimate goal of learning a foreign language is not only knowledge of language but also ability for language (Richards \& Rodgers, 2001: 70) and being able to use it in communicative situations, it is of the utmost importance in the teaching situation to facilitate the progression from practising and learning vocabulary and grammar to authentically communicating in the foreign language. This is not a matter of sequence; it is a process which should be initiated from day one when learners start learning the foreign language. This means that the teacher should facilitate as many opportunities as possible for the learners to actively put the new language to use. However, getting to know the foreign language and being able to communicate in it will need more than just communication on everyday topics. Richards and Rodgers (2001: 153) state that communicative language teaching (CLT) 'promotes fossilization' as there is an 'over-emphasis on communication'. In accordance to this, Penny Ur (2011: 507-508) remarks that:

In spite of the current promotion of communicative and task-based methodologies by ministries of education worldwide, grammatical explanations and exercises continue to be prominent both in coursebooks and in the classroom practice of teachers in schoolbased foreign-language courses.

Thus, the focus in teaching and learning is only on this one aspect of language, whereas the fact that language is also expression is ignored. ${ }^{2}$ Peeters (2008: 29-48) criticises the general conception that language is only a means of communication. According to Peeters, mere communication is the most superficial aspect of language use. Peeters emphasises that language 
competence ('taalvermoë') has the ability to accomplish dialogue by what he terms the 'originarity' of a human being. Language is part of being human and unfolds a person's originarity in dialogue with the other. First, foremost and fundamentally, language is dialogue or conversation, in which it is not only important to understand the information or message, but when we speak something happens in us and to us. Therefore, language as a competence is originarity (see also Mühr, 2009: 221). This means that learning the foreign language cannot only be limited and reduced to using it in everyday situations such as ordering a hamburger or a beer, or asking for directions in an unknown or even non-existent city. Being able to communicate on everyday topics may be one of the goals to be reached, but foreign language learners should be given the opportunity from the start of their language learning journey to express themselves, their thoughts, opinion and emotions - albeit on a level which corresponds to the level of their learning. The purpose of this article is to explore ways to integrate grammar learning and literary texts and provide writing tasks that enable learners to apply the grammar rules they learned in texts of their own. This approach is in accordance with the following principles as stipulated in the Curriculum and Assessment Policy Statement (CAPS) document, which came into effect for South African schools in January 2012. Regarding approaches to teaching language use, a summary of the principles stipulated are given below (Department of Basic Education, 2015: 12):

- Grammar should be taught for constructing texts in their context of use - it is concerned, in other words, with real language.

- The application of grammar should not be restricted to the analysis of isolated sentences - it should explain the way in which sentences are structured to construct whole texts ....

- Use of authentic materials ... must be encouraged.

- Link the language structure with functional uses of the language in different social settings ....

- Focus on meaningful tasks. Acquiring the grammatical rules of the language does not necessarily enable the learner to use the language in a coherent and meaningful way. What interests us then concerns the structure and function beyond the sentence level ....

Although these principles pertain to schools in South Africa, they are also relevant for the teaching and learning of German as a foreign language in general and thus also at university level.

\section{GRAMMAR TEACHING AND LEARNING}

In language teaching and learning, a grammar rule is traditionally taught by demonstrating it in a sentence or sentences (deductive method) and then practising it by applying the rule to a couple of sentences, which are usually not set within any kind of context. Although this may sound very old-fashioned, during school visits as a lecturer for German methodology, I have experienced (student-) teachers using this approach in the classroom time and again. Liamkina and Ryshina-Pankova (2012: 270) bemoan the inability of learners to use grammar rules that we teach in spoken and written communication. Research has proven (Craig \& Lockhard, 1972: 671-84) that just listening to their teacher presenting the grammar rule results in a more shallow level of processing than when learners are involved in figuring out the rule themselves. Introducing grammar inductively challenges the learners' intellectual abilities and results in better memorisation of the material. According to Harald Weinrich (2003), ${ }^{3}$ language is always 
found in texts, and he concludes that language (including vocabulary and grammar) should therefore also be studied in and learned through texts. Taught and learnt in this fashion, grammar is no longer an abstract phenomenon, detached from its natural and authentic context, but is observed and studied in its natural setting within a text. For Weinrich (1985: 239), literary language is of importance - not because it represents the world in a text, but because it portrays and articulates the world in a special, different way. Weinrich argues that the aesthetic dimension of literary language can cause defamiliarisation, which slows down the process of perception by the learner. Through the aesthetic qualities of literary texts, the interest of the learner focuses on the language itself much more strongly than is the case in non-authentic texts $^{4}$ of course work books, which have commonly been used since the rise of the communicative method. Furthermore, by learning the language in its context, aesthetic and cultural aspects are not simply cast aside but play a significant role in observing, studying and learning the language, while the focus shifts from the text with its literary characteristics to the grammar used in the text. In Weinrich's opinion, the learning of grammar is of great importance, unlike in, for example, the audiolingual and audiovisual methods of the 1950s and 60s, where grammar was of no importance because the primary focus was on the ability to communicate in everyday situations (Huneke \& Steinig, 1997: 132; Richards \& Rodgers, 2001: 50). These methods did not enable students to transfer skills acquired to real communication outside the classroom, and often they would find it boring and unsatisfying (Richards \& Rodgers, 2001: $65)$.

Weinrich (2003: 17) criticises the 'didactic texts' used in coursework books for CLT that have been produced specifically for the use of learning a language, which he considers non-authentic texts. Such texts contain only everyday banalities which the learners of German might be using one day in the far future, should they ever visit Germany. Contrary to these texts, literary texts can lead to much motivation in language learning, as Weinrich (1983: 201-203) explains. Authentic texts are linked to the 'real-world' context of the learners and, as such, promote a more learner-centred approach (Littlewood, 2011: 549). Such texts can be anything, for example, newspaper articles, factual texts, interviews or statistics. But Weinrich (1983: 205) advocates the use of literary texts (such as poems, short stories, fairy tales, fables and novels) because, not only have they been written by language experts, but literature also has a very special potential: it can awaken the curiosity and interest of its readers, it has the ability to touch them emotionally, to make them think about and reflect on what they have read. It can make them happy or sad, cause them to laugh or to cry, it can shock or alienate them. Dobstadt and Riedner (2011: 5) point out further functions of literature in the language classroom: literature not only provides exciting topics, but also often serves as an incentive for contemplation and discussion. In addition, it can cause the foreign language as well as the countries where this language is spoken to appear in a different light. Often, literature opens up a new and different take on the way we see the world according to our cultural and interpretative patterns. Through its language and the way it reveals itself, literature helps its readers to become aware of these cultural patterns and enables us to reflect on, process and even change them (Dobstadt \& Riedner, 2011: 8). If readers then get the chance to speak or write about their own experiences or expectations concerning the topic of the text, it is easier for them to write, because they have something to say, they have the urge to express themselves. In this way, the grammar of the foreign language is not the focus of using the language, but it is the medium through which the language is used (Butzkamm, 2002: 221). Instead of practising the correct form of a sentence by writing a number of random sentences, authentic communication with the aim of sharing relevant, context-appropriate information takes place. Utilising literature in this way could be 
a solution to avoiding that learners perceive grammar as being abstract, complicated and boring (Weinrich, 1981: 239).

What this article suggests here is therefore a combined learning outcome: linguistic competence and literary competence should form a single goal. This idea is not new or revolutionary. In the ars grammatica of late antiquity and the Middle Ages, the teaching of grammar was inextricably connected to the reading and interpretation of poets' and writers' works (Weinrich, 1981: 172). In 1630, Comenius (who is considered the father of modern education) recommended in his Great Didactic that language should be learned through usage rather than through its rules. This is the basis on which Weinrich argued for the re-introduction of literature into language teaching in the beginning of the 1980s, not only for mother tongue but also for foreign language teaching. Through the development of text linguistics since the 1960s, in which Weinrich played a significant role, the call to use literature in the teaching environment has grown louder and more frequent. It is not about teaching literature per se, but about using literature as a means to learn the language. Thus, the potential of literature as discussed earlier does not have to be reserved for use in literature studies only, but can unfold while learning the language. The practical consequence of this is that literary texts can create 'literariness in learners' (Miall \& Kuiken, 1999: 24). In addition, the learners create literariness in their texts as they apply and practise the grammar by writing their own texts. Literariness is a feature that is not inherent in a text, but is dependent on the reception of the text. According to Miall and Kuiken (1999: 24), literariness is defined as the occurrence of stylistic or narrative variations that are distinctively (although not uniquely) associated with literary texts that defamiliarise or unsettle reader's conventional understanding of a concept, and prompt modification or transformation of a conventional concept or feeling.

If literary texts form the central communicative and didactic unit in language learning, they communicate with their reader and at the same time make forms of language and speech visible. While the reader extracts information, facts and opinions, he/she at the same time notices how they are embedded in the foreign language (Meier 2006: 193). The text becomes the point of approach and, at the same time, its understanding and interpreting constitutes the goal of the lesson. Through this process, the learners are increasingly enabled to read and understand new and more complex texts and also produce texts which increase in complexity as they progress, in which they express themselves in a very personal and creative way. Creativity, from the Latin verb creare, means to bring forth, to bring to life, and this implies that characteristics such as thinking, feeling and acting are being developed in the learner (Brenner, 1990: 15). The CAPS document by the Department of Basic Education (2015: 11) suggests that creative writing should be closely attached to the study of any literary text, because 'writing activities that demand a close understanding of the text being read can prove very helpful in reaching more creative levels of appreciation on the part of the learner.' This perspective underpins the proposed way of working with literary texts with the incorporation of grammar learning. Furthermore, Liamkina and Ryshina-Pankova (2012: 274) state that acquiring grammar in the functional framework of a textual environment 'is a long-term process of getting exposed to various grammatical patterns in a rich variety of text types and genres.' The importance of working with a wide range of texts is confirmed by the National Curriculum Statement ${ }^{6}$ of the Department of Education (2003: 12), which states that 'the use of a wide range of texts allows learners to explore personal, national and global issues and to construct developing knowledge of the world.' 


\section{PRACTICAL DEMONSTRATION}

In the following part, I want to demonstrate in a practical way how this approach can be implemented. This specific lesson took place in a German class at first-year level at the University of X, with students who have matric German. Austrian poet Erich Fried (19211988) wrote the poem that is being used for this demonstration. For practical reasons, I have translated it into English, although the use of an original English text would certainly be desirable.

\section{Measures}

The lazy are slaughtered the world becomes industrious the ugly are slaughtered the world becomes beautiful the foolish are slaughtered the world becomes wise the sick are slaughtered the world becomes healthy the sad are slaughtered the world becomes happy the old are slaughtered the world becomes young the hostile are slaughtered the world becomes friendly the wicked people are slaughtered the world becomes good

\section{Maßnahmen}

Die Faulen werden geschlachtet

die Welt wird fleißig

die Hässlichen werden geschlachtet

die Welt wird schön

die Narren werden geschlachtet

die Welt wird weise

die Kranken werden geschlachtet

die Welt wird gesund

die Traurigen werden geschlachtet

die Welt wird fröhlich

die Alten werden geschlachtet

die Welt wird jung

die Feinde werden geschlachtet

die Welt wird freundlich

die Bösen werden geschlachtet

die Welt wird gut

In the introductory phase of the lesson, in which previous knowledge of the learners is being activated and their curiosity is piqued, a discussion of the word 'slaughter' takes place which is prompted by questions such as: What do the learners associate with this word? Why do people slaughter animals? Who slaughters animals? What does it mean to slaughter a chicken or a sheep? How would you go about slaughtering an ox? What would you need to do that? During this discussion, it becomes clear to the learners that killing an animal is a bloody affair which requires tools for killing and slaughtering, as well as both know-how and physical strength, unless you use a gun.

Only now do the learners read the poem, after which they have the opportunity to give their impression and opinion of the text. The reaction is mostly one of shock, because in this poem it is not animals that are being slaughtered, but human beings. The discussion is directed towards questions like: Who will determine the laziness, ugliness, foolishness, etc., of people, what criteria could possibly be implemented to make such a judgement? Who will be the judges and who in fact will be the executors of the judgment? Quickly it becomes clear that there is no subject mentioned in the text to indicate who might perform the action. Why is this omitted? How does the text portray this situation by omitting this piece of information? This question leads up to discussing the function of the passive voice. Working in groups, the learners are requested to look at the form of the sentences, how the passive voice is being expressed and what the function of using it might be. Each group formulates the rule as well as a reason for its use. This is then presented shortly by each group to ensure that their conclusion is correct: auxiliary verb (is/are) + past participle of verb. The passive voice is used when the actor is not known, or not really important, or to avoid responsibility for actions taken. This approach (the 
inductive approach) offers the learners the opportunity to be actively involved in discovering the grammatical rule themselves as well as formulating it, which is a much more effective way of ensuring mental retention of the rule (Bimmel, Kast \& Neuner, 2003: 110, 167).

The focus now shifts to the content and structure of the text. Which literary properties did the author use to construct this text? Firstly, the concept 'to slaughter' is a very strong word to use, when contrasted with words such as 'execute' or 'kill'. Because this word is actually used for the killing of animals, it dehumanises the people mentioned here and equates them with animals. Associations with offerings can also be made. The custom of offering sacrifices dates back a long way in history, where Christians as well as heathens used offerings as a means to show their gratitude towards their gods or to ask for favours. In the Bible, for example, the concept of offerings and sacrifice plays a crucial role. The teacher should also mention that the author, Erich Fried, was a Jew, born in Vienna, who fled to England after the annexation of Austria by Nazi Germany in 1938. It seems that he refers to the time of the Nazi regime in this poem, whose policies labelled not only Jews, but also Romani, ethnic Poles, Slavs, Serbs, and persons of colour as 'inferior, non-Aryan sub humans' who were unworthy of life. This eventually culminated in the Holocaust. The poem emphasises the absurdity and ludicrousness of such actions and shows where this attitude of people who think themselves superior to others can lead.

We identify literary devices such as repetition and contrast in the poem. The action of slaughtering is stressed by means of repetition. The use of contrast is a very strong element in the text: lazy - industrious, ugly - beautiful, foolish - wise, sick - healthy, sad - happy, hostile - friendly, wicked - good. In this context, however, the elements contrasted so simplistically are rather ironic and not realistic at all. A discussion is initiated on whether or not the world would indeed become a better place if measures like these were implemented. Surely not; therefore, the learners are requested to try finding alternatives for the verb 'slaughtered': which words could we use to really help and better the world instead of the gruesome and cruel way described in the text? For example, the lazy could be motivated, the ugly could be given makeup, the foolish could be educated, and the sick could be cared for by nurses and doctors.

In groups, the learners now have to formulate a series of sentences in the same fashion which apply to our situation in South Africa. A representative of each group then presents their ideas. Something along the line of the following text may be the result:
A better South Africa
Criminals are arrested and rehabilitated
South Africa becomes safer
Corruption is wiped out
South Africa prospers
Racists are enlightened
South Africa becomes positive
Service delivery happens quickly and effectively
South Africa becomes content
The unemployed are given jobs
South Africa becomes industrious
The hungry ones are fed
South Africa becomes satisfied
Education is promoted
South Africa becomes more knowledgeable and wise 
We conclude from this that positive rather than negative measures should be taken in order to change the world for the better, and that one evil deed should not be repaid with another.

As a homework assignment, the students have to write their own poem, choosing a topic which concerns them personally. For this task, they stick closely to the structure of the given poem and only change the content. The following two examples are the results written by students:

\section{Text 1:}

\section{Student life}

The work is reduced.

Students have more time to socialise.

Fewer tests are written.

Students have less stress.

Fewer lectures are offered.

Students can sleep longer.

No assignments have to be written anymore.

Students can spend more time at Oom Gert's. ${ }^{5}$

But then -

Laziness is promoted.

Knowledge decreases.

Discussions on an intellectual level become obsolete.

Critical thinking no longer takes place.

Students become dull and stupid.

This is not a university anymore.

In this text, the student shifts the topic of the original poem to an aspect pertaining to her own life. She imagines and wishes for studying and student life without the hard work it requires. In the second part of her text, however, she realises that under such circumstances going to university does not make sense anymore. Through this, she seems to motivate herself to take on the challenge to work hard again, realising the importance.

\section{Text 2:}

\section{A better life}

Fast food chains are prohibited

I become healthy and slim

Soccer is prohibited

I become happy

Income tax is prohibited

I become rich

Spiders are prohibited

I become relaxed

My words are heard

But I become restless

As nothing remains

About which I can complain.

The tone in the second text is light and humorous. The text forms a strong contrast to the original text in that it addresses 'problems' which are not really problems. The text expresses aspects of life which cause some kind of trouble, but these are part of society and/or life on earth, even 
though people tend to complain about them. It seems that the author of this little text admits the banality of her suggestions for a better life (as the title suggests) and laughs about herself.

By keeping closely to the structure - and with the help of a dictionary for the vocabulary - the learners need to express their own thoughts; they have the tools to write their own 'poem'. By encouraging them to write in such a way that they express something which is unexpected, humorous, shocking, etc., they often produce real pieces of art which surprise not only the reader, but also themselves.

The learning outcomes with this method are not limited to being able to use the passive voice in the present tense. Other outcomes that go hand in hand are the following:

1. Students have learnt the grammatical function of the passive voice.

2. Their vocabulary on different topics has increased.

3. They have reflected about the fate of less fortunate people in this world.

4. They have criticised political and social evils and have considered solutions.

5. They have written about a personal issue by using the passive voice and have shown common sense and humour.

These outcomes coincide with objectives as stipulated in the National Curriculum Statement (2003: 10) (among others): using language appropriately in real-life context; express and justify their own ideas, views and emotions; use language and their imagination to represent and explore human experience; use language as a tool for critical and creative thinking; express reasoned opinions an ethical issues and values; and interact critically with a wide range of texts.

The use of the passive voice in the present perfect tense, the past, future and progressive tenses must, of course, be addressed at a later stage. One possibility of doing this would be to rewrite the existing text, by changing the heading, thus creating another tense:

\author{
South Africa, 10 years later \\ Criminals were arrested \\ South Africa became safer \\ Corruption was wiped out \\ South Africa prospered \\ Racists were enlightened \\ South Africa became positive \\ Service delivery happened quickly and effectively \\ South Africa became content \\ The unemployed were given jobs \\ South Africa became industrious \\ The hungry ones were fed \\ South Africa became satisfied \\ Education was promoted \\ South Africa became more knowledgeable and wise
}

In the same manner, the other tenses could be used in similar suitable texts based on the learners' own text productions. 


\section{THE LITERARY TEXT AS A PATTERN DRILL}

Through the repetition in the sentences, the text acts almost as a pattern drill. The pattern drill is based on the behaviourist view that learning to speak a foreign language was simply a question of correct habit formation; it was thought that repeating phrases correctly over and over again would lead to mastery of the language (Huneke \& Steinig, 1997: 132). This of course no longer holds, as research has long since established that language learning is a far more complex and creative process. However, in order for learning to take place, connections in the brain are formed through repetition. The well-known neurologist Manfred Spitzer (2006) describes that, in order to remember, the brain has to think about, read and understand content repeatedly: the more often, the better (Spitzer, 2006: 9). The difference to the audio-lingual approaches, however, lies in the fact that the pattern drill should not be a mere reproductive imitation. Learners should apply the new rule on continuously new material in which they are able to express their own personal needs (Butzkamm, 2002: 234; Spitzer, 2006: 76-78). This is exactly what happens when using this approach. First, the learners read, contemplate and discuss the original text. Second, they work together in groups to create a new albeit similar text which is relevant to their own private, political and/or social situation. Finally, they write an individual text in their own time, on a topic which pertains to their own lives. By giving their full attention to using the passive voice in these multiple stages while applying it in texts relevant to their lives, the form is (ideally) literally engraved into their brains.

\section{EVALUATING AND ASSESSING CREATIVE WRITING}

To assess creative texts is a double-edged sword: on the one hand, it seems inappropriate to allocate marks to a piece of 'literary' writing in which students open up to creativity, use their fantasy, try to use new and unfamiliar phrases or metaphorical language and reveal very personal issues about themselves (Mummert, 1989: 37). Mummert argues further that these 'works of art' should be seen as something really special and treated sensitively and respectfully. Only if students know that they do not write for marks but solely for the sake of expressing themselves in the foreign language will they have the courage and the motivation to write freely, spontaneously and unconstrained.

On the other hand, we are forced by our institutions to grade the work done by students and give marks that evidence the progress of students. Therefore, a way must be found to evaluate and assess these creative texts by taking into consideration criteria such as originality, aesthetic elements, wordplay and puns, fantasy, and new ideas. Although Mummert initially advocates not assessing creative writing, she (together with Pommerin) introduces guidelines which take these criteria into consideration and at the same time also consider aspects of communicative appropriateness and grammatical correctness (Pommerin \& Mummert, 2001: 70):

1. Positive impression: What is appealing in the text, what is original, well described, funny or exciting?

2. Are there logical gaps or non-sequiturs? What is unclear, what is jarring about the text?

3. Mistakes and deficits: Are there grammatical mistakes that impede the understanding of the text? Is the text coherent and cohesive?

4. Alternatives: Can more appropriate words, phrases or expressions be used to make the text more interesting?

These criteria show that, even if creative texts by students should ideally not be graded, it is possible to evaluate and grade them in an appropriate way without hurting the authors' feelings. 
My experience in this regard with students at the University of $X$ proved to be very positive. They were eager to know how their texts were received by a reader (in this case their lecturer) and what grammatical and idiomatic mistakes they made, enabling them to learn from their mistakes and giving them the opportunity to do corrections. If marking according to the guidelines provided by the Common European Framework of Reference for the teaching and learning of foreign languages, a written production would be evaluated and graded as follows (Council of Europe, 2001): Marks will be allocated for grammatical correctness, use of vocabulary, orthography, coherence and cohesion, thematic development, and originality. In the end, that means that linguistic competence counts about 50\%, while writing skills, expression and creativeness make up the other $50 \%$.

Acknowledging and showing appreciation for the creative texts and poems of the learners could also be done in the following way: learners could write their poems on a poster in a decorative style. All posters can be exhibited on the notice board in the classroom or in a more public space like the notice boards in the passage of the school or lecture rooms. Alternatively, a booklet can be compiled at the end of the semester or year with the best productions chosen by the students themselves. Another option is that learners collect their texts and poems in a portfolio file. In this way, both they and the teacher have evidence of their work done. Doing corrections can be controlled by the teacher and in this way their progress can be monitored. This may prove to be motivating and encouraging to them.

\section{CONCLUSION}

The learning objective of a lesson as described above is not about one specific goal, for example, grammatical correctness or communicative competence. Rather, the lesson combines objectives that take into consideration the interdependence of grammar, literariness and (oral and written) language production.

It should be stressed that following this approach is not only applicable for teaching and learning German as a foreign language. Because of the general didactic steps described earlier on, this approach could be transferred into any foreign language class. To find appropriate literary texts is easy; once the interested teacher starts looking for suitable texts he or she will realize that they are widely available. Using short texts like poems, short stories, fairy tales, fables or excerpts from novels is practical, as the text can be covered in one or two periods. The methodological approach used can be summarised as follows:

1. Introduction: Activate prior knowledge and introduce the topic of the text. Pique the curiosity of the learners.

2. Read the text.

3. Explain new words and concepts in the text, discuss its content, and identify literary properties and their function.

4. Discover the specific grammatical rule that features in the text and formulate a rule through group work.

5. Practise and apply the new grammar rule. The students practise and apply the rule first in closed exercises (e.g., fill in the open spaces) and then by writing their own text while using the literary text as a model or an example; the crux is that they write about a topic which is relevant to their own personal situation.

This is an example of a generic lesson plan which can be modified as required. The advantage of this is that it not only facilitates an inductive teaching style, but also provides ample room 
for class and group discussions regarding content, style and the grammatical rule, before it is applied and practised in a written text. Working with literary texts means that the readers are exposed to their aesthetic dimension, which has an emotional effect on them. This emotional effect is an excellent way to abolish boredom in the grammar class and at the same time develop a methodology that is extended towards deploying the originarity (as mentioned in the beginning) of the learners. The validity of this approach does not lie in proving (empirically) that the integration of literary texts in the grammar class is better or more effective than traditional ways of grammar teaching, but to demonstrate a more holistic approach in foreign language learning. Furthermore, this approach facilitates core principles of CLT, as stated by Richards and Rodgers (2001: 172), namely, that learners learn the language through using it to express themselves; the communication is therefore authentic and meaningful; an integration of different language skills is involved; and the learning process is enhanced through creative expression. In this way, a deepening of content of communication in the classroom is made possible, making communication more engaging and substantial, as Littlewood (2011: 553) proposes.

\section{ENDNOTES}

${ }^{1}$ This article is based on the unpublished thesis by Weber (2014): 'Die Textgrammatik Harald Weinrichs als Lernergrammatik im DaF-Unterricht.' Available from http://hdl.handle.net/ 2263/43282 [Accessed 20 June 2017].

2 This position was advocated in the 1980s and 1990s of in Germany by authors like Weinrich 1981 and 1983, Werr 1987, Hunfeld 1990, Mummert 1993, Butzkamm 1985 and 2000, and more recently also Dobstad 2009 and Dobstadt and Riedner 2011.

${ }^{3}$ Harald Weinrich is a well-known German classical scholar and author of the textual grammar in French (1980) and German (2003).

${ }^{4}$ According to Adamczak-Krysztofowicz (2003: 85) and Nunan (1989: 54), authentic material refers to 'any material which has not been specifically produced for the purposes of language teaching.' In contrast to this, the glossary of the CAPS document defines authentic texts as 'texts which have a practical function and are not literary' (Department of Basic Education, 2015: 71). For the purpose of this article, the definition for authentic texts is being understood in accordance with Adamczak-Krysztofowicz and Nunan.

${ }^{5}$ Oom Gert's is a popular fast food restaurant on campus.

${ }^{6}$ The National Curriculum Statement was amended and the CAPS was developed. CAPS is an outflow of the philosophy of Outcomes-based Education.

\section{REFERENCES}

WEBER, A. 2014: Die Textgrammatik Harald Weinrichs als Lernergrammatik im DaFUnterricht [Harald Weinrich's Textual Grammar adapted as a Learner's Grammar in the teaching of German as a foreign language]. Available from http://hdl.handle.net/2263/43282 [Accessed 20 June 2017].

ADAMCZAK-KRYSZTOFOWICZ, S. 2003. Texte als Grundlage der Kommunikation zwischen Kulturen. Eine Studie zur Kultur- und Landeskundevermittlung im DaFStudium in PolenHamburg: Kovač (Orbis). 
BIMMEL, P, B KAST \& G NEUNER. 2003. Deutschunterricht planen. Arbeit mit Lehrwerkslektionen München: Goethe-Institut Inter Nationes.

BRENNER, G. 1990. Kreatives Schreiben. Ein Leitfaden für die Praxis mit Texten JugendlicherFrankfurt: Scriptor.

BUTZKAMM, W. 1985. Literarische Texte als SprachlerntexteIn: M Heid \& das Referat des Goethe Instituts in München (Eds.), New Yorker Werkstattgespräch 1984: Literarische Texte im FremdsprachenunterrichtNew York: Goethe House. 89-105.

BUTZKAMM, W. 2002. Psycholinguistik des Fremdsprachenunterrichts. 3., neubearbeitete AuflageTübingen: Francke.

COUNCIL OF EUROPE. 2001. Common European framework of reference of languages: Learning, teaching, assessment. Available from https://www.coe.int/t/dg4/linguistic /source/framework_en.pdf [Accessed: 20 June 2017].

CRAIG, F \& R LOCKHARD. 1972. Levels of processing: Framework for memory research. Journal of Verbal Learning and Verbal Behavior, 11:671-84.

DEPARTMENT OF EDUCATION. Republic of South Africa. 2003. National Curriculum Statement Grades 10 - 12 (General). Languages: German Second Additional Language. Available from http://dlvsa.co.za/files/2015/04/ German-2nd-Add-Language.pdf [Accessed: 28 November 2017].

DEPARTMENT OF BASIC EDUCATION. Republic of South Africa. 2015. Curriculum and Assessment Policy Statement (CAPS). Grades 7 - 9. Languages. German Second Additional Language. Available from https://www.education.gov.za/Portals/0/CD/National\%20Curriculum\%20Statements\%2 0and\%20Vocational/CAPS\%20German\%20SAL\%20SP\%20Final.pdf?ver=2015-06-09112803-043 [Accessed: 28 November 2017].

DOBSTADT, M. 2009. 'Literarizität' als Basiskategorie für die Arbeit mit Literatur in DaFKontexten. Zugleich ein Vorschlag zur Neuprofilierung des Arbeitsbereichs Literatur im Fach Deutsch als Fremdsprache Deutsch als Fremdsprache, 46(1): 21-30.

DOBSTADT, M \& R RIEDNER. 2011. Fremdsprache Literatur. Neue Konzepte zur Arbeit mit Literatur im Fremdsprachenunterricht. Fremdsprache Deutsch Zeitschrift für die Praxis des Deutschunterrichts, 44: 5-14.

HUNEKE HW \& W STEINIG. 1997. Deutsch als Fremdsprache. Eine Einführung. Berlin: Erich Schmidt.

HUNFELD, H. 1990. Literatur als Sprachlehre. Ansätze eines hermeneutisch orientierten Fremdsprachenunterrichts. Berlin: Langenscheidt.

LIAMKINA, O. \& M RYSHINA-PANKOVA. 2012. Grammar dilemma: Teaching grammar as a resource for making meaning. The Modern Language Journal, 96(2):270-289.

LITTLEWOOD, W. 2011. Communicative language teaching: An expanding concept for a changing world. In: E Hinkel (Ed.), Handbook of research in second Language teaching and learning. Volume II. New York: Routledge. 541-557.

MEIER, J. 2006. Angewandte Textlinguistik und DaF-Unterricht. In: M Scherner \& A Ziegler (Eds.), Angewandte Textlinguistik. Perspektiven für den Deutsch- und Fremdsprachenunterricht. Tübingen: Narr. 193-203.

MIALL DS \& D KUIKEN. 1999. What is literariness? Three components of literary reading. Discourse Processes, 28:121-138.

MÜHR, S. 2009. Authenticity and originarity in foreign language learning in the diaspora. Stellenbosch Papers in Linguistics PLUS, 38:215-231.

MUMMERT, I. 1993. Literatur im Unterricht Deutsch als Fremdsprache. Deutsch als Fremdsprache, 30(2):110-111. 
NUNAN, D. 1989. Designing tasks for the communicative classroom. Cambridge: Cambridge University Press.

PEETERS, L. 2008. Taalvermoë en originariteit [Language competence and originarity]. Acta Academica, 40(2): 28-52.

POMMERIN, G \& I MUMMERT. 2001. Ansätze einer kreativitätsorientierten Textanalyse und Textüberarbeitung (1). Deutsch als Fremdsprache, 38(2):67-76.

RICHARDS, JC \& TS RODGERS. 2001. Approaches and methods in language teaching. New York: Cambridge University Press.

SPITZER, M. 2006. Lernen. Gehirnforschung und die Schule des Lebens. Heidelberg: Spektrum.

UR, P. 2011. Grammar teaching: Research, theory, and practice. In: E Hinkel (Ed.), Handbook of research in second language teaching and learning. Volume II. New York: Routledge. 507-522.

WEINRICH, H. 1981. Von der Langeweile des Sprachunterrichts. Zeitschrift für Pädagogik, 27:169-185.

WEINRICH, H. 1983. Literatur im Fremdsprachenuntericht - ja, aber mit Phantasie. Die neueren Sprachen, 82(3):200-216.

WEINRICH, H. 1985. Wege der Sprachkultur. Stuttgart: Deutsche Verlags-Anstalt.

WEINRICH, H. 2003. Textgrammatik der deutschen Sprache. Unter Mitarbeit von Eva Breindl, Maria Thurmair, Eva-Maria Willkop. 2. Auflage. Mannheim: Dudenverlag.

WERR, C. 1987. Literatur zum Anfassen. Vorschläge zu einem produktiven Umgang mit Literatur. München: Hueber.

\section{BIOGRAPHICAL NOTE}

Dr Angelika Weber is a lecturer for German at the University of Pretoria. Her research interests are the teaching of German as a foreign language, didactics of literature and intercultural learning. She has also published several articles on the collages of Herta Müller. 